American Journal of Biochemistry and Biotechnology 5 (3): 126-136, 2009

ISSN 1553-3468

(C) 2009 Science Publications

\title{
Camel's Milk Protects Against Aluminum Chloride-Induced Normocytic Normocromic Anemia, Lipid Peroxidation and Oxidative Stress in Erythrocytes of White Albino Rats
}

\author{
Fahaid Al-Hashem \\ Department of Physiology, College of Medicine, \\ King Khalid University, Abha 61421, Saudi Arabia
}

\begin{abstract}
Problem statement: Aluminum (Al) is an indifferent element from a toxicological point of view. In recent years, however, Al has been implicated in the pathogenesis of several clinical disorders. One of the most frequently described problem in aluminum toxicity is anemia. The present study was carried out to determine the effectiveness of Camel's milk in alleviating the toxicity of aluminum chloride $\left(\mathrm{AlCl}_{3}\right)$ on certain hematological parameters, lipid peroxidation and oxidative stress enzyme in the RBC's of white albino rats. Approach: Ten rats per group were divided into three treatment groups: Group one were rats given normal saline and served as control group, group two were rats treated with $1 \mathrm{ml}$ of $\mathrm{AlCl}_{3}\left(0.5 \mathrm{mg} \mathrm{kg}^{-1}\right.$ body weight) and named $\mathrm{AlCl}_{3}$ treated rats, group 3 were rat treated with $1 \mathrm{ml}$ fresh camel's milk 10 min before the administration of $\mathrm{AlCl}_{3}\left(0.5 \mathrm{mg} \mathrm{kg}^{-1}\right.$ body weight) and named Camel's milk and $\mathrm{AlCl}_{3}$ treated rats. Rats were orally administered their respective doses every day for 30 days. Evaluations were made for hematological parameters in the blood and for lipid peroxidation and oxidative stress enzymes activities in the RBC's. Results: Results obtained showed that oral $\mathrm{AlCl}_{3}$ treatment caused a significant decrease $(\mathrm{p}<0.05)$ in total erythrocytes count, blood Hemoglobin (Hb), hematocrite (PCV) and Serum iron levels, where as the values of Mean Corpuscular Volume (MCV), Mean Hemoglobin Concentration (MHC), Mean Corpuscular Hemoglobin Concentration (MCHC) and Total Ion Binding Capacity (TIBC) didn't change. Also oral administration of $\mathrm{AlCl}_{3}$ induced free radicals and as a result caused an increase the concentration of Thiobarbituric Acid Reactive Substances (TBARS) and decreased activities of Superoxide Dismutase (SOD) and Catalsae (CAT) in the RBCs homolysate. The oral administration of Camel's milk before the administration of $\mathrm{AlCl}_{3}$, alleviated it's toxic effect. Camel's milk administration resulted in a significant increase $(\mathrm{p}<0.05)$ in the in total erythrocytes count, blood hemoglobin $(\mathrm{Hb})$, hematocrite (PCV) and Serum iron with No change in the values of MCV, MHC, MCHC and TIBC when compared to $\mathrm{AlCl}_{3}$ treated rats. Camel's milk reduced free radicals production and oxidative stress status in the RBC's noticed by the significant decreased levels of TBARS and increased activities of SOD and CAT when compared to $\mathrm{AlCl}_{3}$ treated rats. Conclusion: our data proved that there is an alternation in the hematological parameters and antioxidant system in the red blood cells of rats administered aluminum chloride orally, whereas oral administration of Camel's milk prior the administration of Aluminum chloride protects the red blood cell form toxic effect of aluminum.
\end{abstract}

Key words: Aluminum chloride, red blood cells, erythrocytes, oxidative stress, camel's milk

\section{INTRODUCTION}

Aluminum (Al), the third most abundant element of the Earth's crust, is a nonessential and toxic metal in humans ${ }^{[1]}$. Due to its abundance, every organism contains small quantities of aluminum and it can be found in practically all of the tissues of mammals, including the brain, liver, kidney, heart, blood and bones ${ }^{[2]}$.

Particular sources of Aluminum include corn, yellow cheese, salt, herbs, spices, tea, cosmetics and Aluminum cooking utensils and containers ${ }^{[3]}$. Also,
Aluminum is widely used in food additives and toothpaste ${ }^{[4]}$. Aluminum compounds are widely used in medicine e.g., antacids, phosphate binders, buffered aspirins, vaccines and allergen injections ${ }^{[5-7]}$. In addition, aluminum is added to drinking water for purification purposes ${ }^{[8]}$.

Aluminum has the potential to be toxic for humans and animals The human toxicological effects include encephalopathy $^{[9]}$, bone disease ${ }^{[10]}$, Skeletal system disease $^{[11]}$ Alzheimer's disease ${ }^{[12]}$. And blood problems $^{[13]}$. 
The most frequently described blood problem in aluminum toxicity is anemia. It is important to note, that this disorder was observed in patients after dialyses when aluminum ions were present in dialysis fluid ${ }^{[14]}$; also in the case of laboratory animals that were administered solutions of aluminum salts orally, intraperitonally, or intravenously ${ }^{[13,15,16]}$.

Aluminum has a direct effect on hematopoiesis ${ }^{[17]}$. Excess aluminum has been shown to induce anemia $^{[13,15,16]}$. Daily injections of aluminum into rats produced severe anemia within 2-3 weeks ${ }^{[16]}$. Previous investigators proposed that Aluminum may cause anemia through decreased heme synthesis ${ }^{[18,19]}$, decreased globulin synthesis and increased hemolysis ${ }^{[20,21]}$. Patients with anemia from aluminum toxicity often have increased reticulocyte counts, decreased hemoglobin concentration, decreased hematocrite value, decreased mean corpuscular volume and decreased mean corpuscular hemoglobin ${ }^{[16]}$.

These toxic effects of aluminum on RBCS have been suggested to be due to the generation of reactive oxygen species and induction of oxidative stress ${ }^{[22]}$, which results in the oxidative deterioration of cellular lipids (through lipid peroxidation), proteins and $\mathrm{DNA}^{[22,23]}$. So, these toxic effects of aluminum appear to be mediated, at least in part, by free-radical generation ${ }^{[24,25]}$. Recent research shows that aluminum may induce changes in the activity of a number of antioxidative enzymes (xanthine oxidase, glutathione peroxidase, superoxide dismutase ${ }^{[24]}$.

Several studies have implicated lipid peroxidation as one of the molecular mechanisms underlying aluminum toxicity in vitro and in vivo ${ }^{[26-30]}$. A recent report suggests that aluminum can induce morphological and functional alterations in erythroid cells by a direct action on circulating erythrocytes ${ }^{[31]}$, suggesting membrane alterations due to lipid peroxidation mechanisms. In line with this, aluminum decreases erythrocytic membrane fluidity ${ }^{[32]}$. However, a casual link between hematological changes and lipid peroxidation after exposure to aluminum is lacking in the literature.

Also, Aluminum may have a direct effect on iron metabolism; it influences absorption of iron via the intestine, it hinders iron's transport in the serum and it displaces iron's binding to transferring ${ }^{[33,34]}$. The major forms of aluminum in blood circulation has been reported to be in complex with transferring using immuno-affinity chromatography and spectrophotometric titration techniques ${ }^{[35]}$. Transferrin is known primarily for its role in the transport and cellular uptake of iron but is also the major serum binding protein for aluminum ${ }^{[36,37]}$. previous studies showed that aluminum bound to serum transferring and the complex of aluminum-transferrin interacts with the same receptors as iron-transferrin ${ }^{[38]}$, this receptormediated cellular uptake appears to be an important factor in the uptake of aluminum by the tissues ${ }^{[39]}$.

Several studies suggest that chronic exposure to relatively high doses of aluminum can change iron metabolism in different animal species ${ }^{[15,40,41]}$. However, the findings are not always in the same direction. In fact, some studies have indicated a reduction in iron in serum of rats exposed to high levels of aluminum ${ }^{[40,41]}$, whereas other investigators have found no alterations or an increase in iron stores after exposure to aluminum ${ }^{[10,42]}$.

Consequently, data concerning the mechanism of Aluminum toxicity on hematological system and iron metabolism after administration of aluminum are contradictory and seem to depend on the conditions of toxicity, which refer mainly to different doses and different routes of administration.

Most of experimental studies on aluminum toxicity in an animal model have been preformed with the use of this metal in a soluble form ${ }^{[43]}$ or with certain metal $^{[44]}$. However, in has been reported that in most of studies done to demonstrate the toxic effect of aluminum chloride in animals, the chosen routes of $\mathrm{Al}$ administration (i.e., intraperitoneal, intravenous and parenteral) do not simulate the main route by which human population is exposed to Aluminum. There are two main routes by which aluminum enters the body: Pulmonary and oral. The bulk of inhaled contaminants in the air are aluminosilicates. Although only a small portion of aluminum is absorbed by the gastrointestinal tract, oral intake represents the route with greatest toxicological implications ${ }^{[45]}$. For this reason our current study was carried out by oral administration of Aluminum chloride.

It was reported that the components of camel's milk is different from any other milk and play a major role in its therapeutic action. Camels milk is rich in minerals such as potassium, zinc and magnesium and has high concentrations of vitamin $\mathrm{B} 2, \mathrm{C}$ and $\mathrm{E}^{[45]}$.

In India, camel's milk is used therapeutically against dropsy, jaundice, problems of the spleen, tuberculosis, asthma, anemia, piles and diabetes ${ }^{[47]}$.

The conflicting data related to the basis of the toxic effects of orally low dose of aluminum chloride administration on erythropoiesis and on iron metabolism do not allow definitive conclusions. Also, in our survey, we didn't find any study dealt with the therapeutic effect of Camel's milk against the bad effect of Aluminum chloride on blood of rats. Therefore the aim of our study was to investigate a possible protective 
influence of Camel's milk treatment on some hematological parameters, Iron metabolism, lipid peroxidation and antioxidant defense system in the blood of rats treated with Aluminum. The following parameters were determined in the blood to confirm anemia: Red Blood Cells count (RBCs), Hematocrite value $(\mathrm{Hct})$, Hemoglobin $(\mathrm{Hb})$, blood indices, iron concentration, Total Iron Binding Capacity (TIBC). TBARS in the RBC's was determined as an indicator of lipid peroxidation status. Also, the following antioxidant enzymes activities were determined in the RBC's: Superoxide Dismutase (SOD) and Catalase (CAT).

\section{MATERIALS AND METHODS}

Preparing of Camel's milk Samples: Milk samples were supplied every day early morning by farmers from Abha region (Southeastern province of Saudi Arabia), Milk was collected into sterile bottles and then transported in cool boxes to our laboratory. Farmers collected the milk by hand milking.

Chemicals: Aluminum chloride chloride $\left[\mathrm{AlCl}_{3} \times 6\right.$ $\mathrm{H}_{2} \mathrm{O}$ ] was purchased from Aldrich chemical Company (USA).

Experimental design: Rats weighing between 230$250 \mathrm{~g}$ were supplied from the animal house at College of Medicine at King Khalid University. The rats were divided into 10 rats/cage, the rats were housed in plastic cages at a temperature regulated $\left(22^{\circ} \mathrm{C}\right)$ and humidity (55\%) controlled room with a $12 \mathrm{~h}$ light/12 h dark cycle. A water and standard pellet diet were available ad libitum throughout the experimental period.

For determination of daily orally aluminum chloride dose we followed the guidelines of drug institute in which they recommend that the drug applied to rodents must be 4 to 10 folds of daily human intake $^{[48]}$. In reference to $\mathrm{FAO} / \mathrm{WHO}$ expert committee on food additives, they reported that the daily intake of aluminum in adult human is $6-14 \mathrm{mg} / 70 \mathrm{~kg}^{[49-51]}$, which gives a daily intake of aluminum ranges between $0.0857-0.2 \mathrm{mg} \mathrm{kg}^{-1}$. In our experiment the daily dose of aluminum chloride given to rats was $0.5 \mathrm{mg} \mathrm{kg}^{-1}$ which exceeded 6 folds of minimal dose and 2.8 fold of maximal dose on average of 4 fold the daily aluminum intake in human.

Rats were divided into three group each of ten rats, all treatments were carried out for 30 days and they were given orally by using special cavage needle. Rats received a single dose of the selected treatment every day and were treated as follows:

Group 1: were control rats received a single daily dose of normal saline orally.

Group 2: were rats given a daily single dose of aluminum chloride at a final concentration of $0.5 \mathrm{mg} \mathrm{kg}^{-1}$ and name $\mathrm{ALCL}_{3}$-treated rats.

Group 3: were rats given a single dose of $1 \mathrm{~mL}$ Camel's milk $10 \mathrm{~min}$ before the oral administration of Aluminum chloride with same concentration used in group two and named Camel's milk-ALCL $\mathrm{L}_{3}$ treated group.

Physiological and biochemical analyses: After the treatment ( $24 \mathrm{~h}$ after the last administration), the animals were sacrificed by decapitation always between 8:00 and 10:00 am and fresh blood was immediately collected into heparinized test tubes for routine hematological analysis. A second blood fraction was collected without anticoagulant and centrifuged at $5000 \mathrm{rpm}$ for $10 \mathrm{~min}$ and used for determination of iron content and TIBC in serum. Some heparinized Blood were used for preparation of homolysate for determination of TBARS, SOD and CAT activities. The following hematological parameters were determined in the plasma: Erythrocytes were counted on hemocytometer using a light microscope at $40 \times 10$ magnification. Blood samples were diluted to 200 times by physiological saline ( $0.9 \%$ sodium chloride solution) before counting. Hematocrite value were determined by the method of Strumia et $a l^{[52]}$. The hemoglobin concentration was determined by the cyanmethemoglobin method $^{[53]}$. Mean Corpuscular Volume (MCV), Mean Hemoglobin Concentration (MHC) and Mean Corpuscular Hemoglobin Concentration (MCHC) were calculated in accordance with the models given by Wintrobe ${ }^{[54]}$. Iron and TIBC in serum were determined using cell using Commercial available kits (human), according to manufacture's instruction.

Preparation of hemolysate: After collecting blood samples in heparinized tubes, centrifugation was performed at $1000 \mathrm{~g}$ for $15 \mathrm{~min}$ to remove the buffy coat. The packed cells obtained at the bottom were washed thrice with phosphate buffer saline $(0.9 \% \mathrm{NaCl}$ 
in 0.01 $\mathrm{M}$ phosphate buffer, $\mathrm{pH}$ 7.4). A known amount of erythrocytes was lysed with hypotonic phosphate buffer. The hemolysate was obtained after removing the cell debris by centrifugation at $3000 \mathrm{~g}$ for $15 \mathrm{~min}$ and used for determination of reduced glutathione levels.

Measurement of TBARS levels SDO and CAT activity: Superoxide dismutase activity in the red blood cells homolysate was measured by using commercial kits (Biovision, K335-100). The activity was expressed as $\mathrm{U} \mathrm{mL}^{-1}$.

Catalase Activity (CAT) in the red blood cells homolysate was determined by using commercial kit (biovision K773-100. Cat activity was expressed as $\mathrm{U} / \mathrm{ml}$. One unit of catalase is the amount of catalase decomposes $1.0 \mu$ mol of $\mathrm{H}_{2} \mathrm{O}_{2}$ per min at $\mathrm{pH} 4.5$ at $25^{\circ} \mathrm{C}$.)

The concentration of Thiobarbituric Acid Reactive Substances (TBARS) in the RBCs homolysate was determined by the method of Okhawa ${ }^{[55]}$. In brief, the reaction mixture contained $0.1 \mathrm{~mL}$ of homolysate, $0.2 \mathrm{~mL}$ of sodium dodecyl sulfate, $1.5 \mathrm{~mL}$ of acetic acid and $1.5 \mathrm{~mL}$ of aqueous solution of thiobarbituric acid. The $\mathrm{pH}$ of $20 \%$ acetic acid was pre-adjusted with $1 \mathrm{M}$ $\mathrm{NaOH}$ to 3.5. The mixture was made up to $4 \mathrm{~mL}$ with distilled water and heated at $95^{\circ} \mathrm{C}$ for $1 \mathrm{~h}$, in a water bath. After cooling, $1 \mathrm{~mL}$ of distilled water and $5 \mathrm{~mL}$ of mixture of n-butanol and pyridine (15:1) were added and mixture was shaken vigorously on a vortex mixer. The absorbance of the upper organic layer was read at $532 \mathrm{~nm}$. The values were expressed as $\mathrm{mM} \mathrm{mL}^{-1}$.

Statistical analysis: Data are expressed as mean \pm SD. Student's t-test was used to determine the difference between groups. Statistical significance was considered at $\mathrm{p}<0.05$.

\section{RESULTS}

Table 1 shows the results of total RBC's count, hemoglobin concentration $(\mathrm{Hb})$, Hematocrite value (PCV) and red blood cell indices (MCV, $\mathrm{MCH}$ and $\mathrm{MCHC}$ ) in all groups of rat. Rats administered Aluminum chloride orally showed decreased values of erythrocyte counts, hemoglobin and hematocrite, but the levels of MCV, MCH and MCHC didn't change when compared to rats received normal saline orally. On other hand oral administration of Camel's milk before the administration of aluminum chloride to rats significantly increased these parameters to their normal levels when compared to rats administered cadmium only.
Table 1: Red Blood Cells (RBC's) count, Hematocrite (Hct) value and Hemoglobin $(\mathrm{Hb})$ concentration in the blood of control rats, aluminum treated-rats and Camel's milk and aluminum treated rats

\begin{tabular}{llcl}
\hline Parameters & \multicolumn{1}{c}{ Control } & \multicolumn{1}{c}{$\mathrm{AlCl}_{3}$} & \multicolumn{1}{c}{$\mathrm{AlCl}_{3}+$ milk } \\
\hline RBC's $\left(X 10^{6} \mathrm{~mm}^{3}\right)$ & $7.02 \pm 0.089$ & $4.89 \pm 0.284^{*}$ & $7.25 \pm 0.093^{*}$ \\
Hematocrite $(\%)$ & $57.76 \pm 0.856$ & $37.68 \pm 0.633^{*}$ & $58.40 \pm 0.432^{*}$ \\
Hemoglobin $\left(\mathrm{g} \mathrm{dL}^{-1}\right)$ & $16.73 \pm 0.335$ & $9.78 \pm 0.509^{*}$ & $16.78 \pm 0.944^{*}$ \\
MCV (fl) & $82.20 \pm 0.85$ & $77.10 \pm 0.56$ & $80.46 \pm 0.63$ \\
MCH (pg) & $23.83 \pm 0.94$ & $20.01 \pm 1.1$ & $23.12 \pm 0.98$ \\
MHCH $\left(\mathrm{g} \mathrm{dL}^{-1}\right)$ & $28.97 \pm 1.1$ & $25.97 \pm 0.88$ & $28.97 \pm 1.3$ \\
\hline
\end{tabular}

Values are given as mean \pm SD for groups of six animals each. Values are statistically significant at $* p<0.05$. Cadmium treated rats were compared with control rats; Camel's milk cadmium treated rats were compared with Cadmium treated rats

Table 2: Iron and TIBC levels in the serum of control rats, Aluminum treated-rats and camel's milk and cadmium treated rats

\begin{tabular}{lllc}
\hline Parameters & Control & $\mathrm{AlCl}_{3}$ & $\mathrm{AlCl}_{3}+$ milk \\
\hline Iron & $291.6 \pm 5.41$ & $202.1 \pm 4.44^{*}$ & $287.00 \pm 2.87 *$ \\
TIBC & $607.0 \pm 8.78$ & $602.0 \pm 5.94$ & $605 \pm 6.18$ \\
\hline
\end{tabular}

Values are given as mean \pm SD for groups of six animals each. Values are statistically significant at $* \mathrm{p}<0.05$. Cadmium treated rats were compared with control rats; Camel's milk Cadmium treated rats were compared with Cadmium treated rats. $\mathrm{Fe}$ concentration and TIBC are expressed as $\mu \mathrm{g} \mathrm{dL}^{-1}$

Table 3: TBARS levels and SDO and CAT activities in the RBC's of control rats, Aluminum treated-rats and Camel's milk and aluminum treated rats

\begin{tabular}{lcll}
\hline Parameters & Control & $\mathrm{AlCl}_{3}$ & $\mathrm{AlCl}_{3}+$ milk \\
\hline SOD $\left(\mathrm{U} \mathrm{mL}^{-1}\right)$ & $8.37 \pm 0.25$ & $2.22 \pm 0.16^{*}$ & $8.110 \pm 0.28^{*}$ \\
CAT $\left(\mathrm{U} \mathrm{mL}^{-1}\right)$ & $94.40 \pm 2.3$ & $57.0 \pm 3.7^{*}$ & $95.10 \pm 4.05^{*}$ \\
TBARS $\left(\mathrm{mM} \mathrm{mL}^{-1}\right)$ & $28.20 \pm 2.10$ & $31.3 \pm 1.01^{*}$ & $27.36 \pm 065^{*}$ \\
\hline
\end{tabular}

Values are given as mean \pm SD for groups of six animals each. Values are statistically significant at $* \mathrm{p}<0.05$. Cadmium treated rats were compared with control rats; Camel's milk Cadmium treated rats were compared with Cadmium treated rats

The levels of serum Iron and TIBC are presented in Table 2. There was a significant decrease in the levels of iron in the rats treated with aluminum chloride. Administration of camel's milk into rats before the administration of aluminum chloride caused a significant increase in the levels of serum iron. TIBC levels didn't change in all treated group.

Table 3 shows the activity of Superoxide Dismutase (SOD) and Catalase (CAT) as well as Thiobarbituric Acid Reactive Substances (TBARS) concentration in RBC's of all groups of rats. Aluminum chloride treated-rats showed a significant decrease in the activity of these enzymes (SOD and CAT) and a significant increase in the level of TBARS. Rats treated with Camel's milk and aluminum chloride showed a significant increase in the activity of SOD and CAT as well as a significant decrease in the levels TBARS in the RBC's of the treated rats when compared to cadmium treated rats. 


\section{DISCUSSION}

The present results show hematological modifications associated with orally administered aluminum chloride in rats and show the reversible effect of Camel's milk on these modifications.

Several lines of evidence have confirmed the fact that aluminum can induce anemia ${ }^{[13,15,16,31]}$. It is essential to evaluate the level of anemia by the following measurements: RBC's count hemoglobin concentration, hematocrite and red blood cell indices (MCV, MCH and MCHC).

In aluminum chloride oral administered rats, a reduction in erythrocyte count, haemoglobin levels and hematocrite values were observed which is in agreement with Vittori et $a l^{[27]}$ and other authors $^{[15,16,18,56]}$ who found similar effect following aluminum administration with different routs. Values of Mean Corpuscular Volume (MCV), Mean Corpuscular Hemoglobin (MCH) and Mean Corpuscular Hemoglobin Concentration (MCHC) were not affected by Aluminum chloride indicating that, in our experimental rats, the rats developed normocytic and normocromic anemia.

The reduction in RBC's, hematocrite value indicate to possible hemolytic effect of aluminum chloride. Hemolytic activity of this element is due to changes in cell membrane of red blood cells. It has been reported that in the presence of Aluminum ions, human erythrocytes lost their typical biconcave shape, turning into acanthocytes and stomatocytes ${ }^{[27]}$. Aluminum, like other xenobiotics, generates free radicals and reactive oxygen species in cells, which cause fatty acid superoxides and oxidation of cellular membrane proteins, which leads to reduction of membrane fluidity and in consequence to damage of cellular membrane ${ }^{[57]}$. Also, It has been reported that aluminum intoxication lead to a decrease in activity of membrane ATPases and in effect to cellular accumulation of adenylates and to reduce rate of ATP: ADP converting. This lead to diminish of energy essential to maintenance of membrane integrity and to red blood cells dysfunction and so haemolysis ${ }^{[58,59]}$.

The reduced level of hemoglobin can be associated with hemolysis or disturbances in heme biosynthesis as a result of inhibit linking of iron with heme and drop in activity of enzymes taking part in heme biosynthesis, mainly dehydratase of delta-aminolevulonic acid (ALA-D) ${ }^{[5,32,59,60]}$, also, Ganchev et al. ${ }^{[61]}$ reported that aluminum treatment in rat hinderes hemoglobin synthesis and erythroid cell maturation.
Aluminum can interact with iron metabolism $^{[5,15,41,42,62]}$ and iron depletion may occur after aluminum intoxication ${ }^{[63,64]}$. There are contradictory data in literature about transferrin saturation after $\mathrm{Al}$ exposure. Some studies have reported that Aluminum intoxication decreases the percentage of transferrin saturation (15). Furthermore, iron seems to influence the transferrin binding of $\mathrm{Al}$ by lowering the affinity of transferrin for Aluminum ${ }^{[65]}$. Conversely, Vittori et al. ${ }^{[31]}$ did not observe changes in plasma iron concentration, TIBC or transferrin saturation in rats chronically exposed to $\mathrm{Al}$, although anemia signs were observed in these animals. In our study, the oral exposure to Aluminum chloride decreased serum iron but TIBC (the amount of Fe3+ needed to fully saturate plasma transferrin) did not change after aluminum treatment. It would be speculated that Aluminum is present at transferring sites in iron-deficient (Al-exposed) rats.

Previous research has indicated that oxidative stress has an important role in aluminum toxicity ${ }^{[26-30]}$. In agreement with this is the hypothesis by Joshi ${ }^{[66]}$ that aluminum interferes with iron ions, particularly with trivalent iron ions which participate in oxidoreduction. This results in increased production of free radicals. Kong et $a l .^{[67]}$ proposed that aluminum builds a complex with $\mathrm{O}_{2}$.

In this study, oral administration of aluminum chloride produced a significant increase in TBARS in the RBC's suggesting increased lipid peroxidation as a result of generation of free radicals, TBARS has been associated with reduction of membrane fluidity ${ }^{[68]}$ The presence of such changes suggests that the alterations on erythrocyte parameters in this group are due to an enhanced intravascular hemolysis as a result of oxidative stress and lipid peroxidation in the circulating erythrocytes. Our result are in agreement with Vittori et al. ${ }^{[15]}$ who reported that aluminum exposure can induce alterations of erythroid cells by a direct action on circulating erythrocytes suggesting membrane alterations due to lipid peroxidation. Our result is the first one that shows an increase in the levels of TBARS in Aluminum chloride intoxicated rats.

Maintenance of normal cellular functions in the presence of oxygen largely depends on the efficiency of the defense mechanisms against free-radical mediated oxidative stress. To prevent biological macromolecules from oxidative damage, antioxidant enzymes are considered to be the first line of cellular defense. The most common antioxidant enzymes in the biological systems are SOD and CAT. Our results indicate that 
erythrocyte catalase activity is significantly lower in the aluminum-exposed group. Mena et al. ${ }^{[69]}$ had a similar finding of reduced catalase activity in subjects with increased amounts of free radicals during an intensive physical strain. This inhibition in CAT activity could be a result of the oxidation of catalase sulfhydryl groups ${ }^{[70]}$ or due to decrease synthesis.

Previous reports on SOD activity and aluminum exposure are controversial. Shainkin Kestenbaum et al. ${ }^{[71]}$ and Hasanoglu et al. ${ }^{[72]}$ reported significantly decreased SOD activity in erythrocytes of haemodialysed patients, but Abd-Elghaffar et al. ${ }^{[73]}$ reported decreased brain SOD activity in rabbits exposed to aluminum chloride. In contrast, an other in vitro study ${ }^{[74]}$ reports unchanged SOD activity. Our study show a significant decrease in erythrocyte SOD activity in rats exposed to aluminum chloride.

Camel's milk oral administration 10 min before the administration of aluminum chloride in resulted in a reverse action of aluminum chloride, it maintain all the above altered hematological parameters within their normal levels. Camel's milk protect the rats from anemia induced by aluminum chloride; in rats treated with $1 \mathrm{ml}$ camel's milk with aluminum chloride orally, a significant increase in the RBC's count, hemoglobin, hematocrite and iron serum levels were shown when compared to rats administered aluminum chloride only. Also, oral administration of camel's milk resulted in a significant decrease in the levels of TBARS and an increase in the enzymatic components of oxidative system: SOD and CAT in the RBC's, when compared to rats received aluminum chloride only.

According to our result, it could be concluded a protective effect of Camel's milk against aluminum chloride induced toxicity in the red blood cells of rats. Camel's milk reduced the risk of anemia and oxidative stress in the erythrocytes of rats. Such effect could be due to a possible chelating effect of aluminum chloride but further studies are required.

Camel's milk Contain high levels of Vitamins including Vitamin $\mathrm{C}$ and $\mathrm{E}$ which considered potent antioxidants that help in preventing tissue damage caused by production of free radicals. These vitamin may play a major role in the protective effect of Camel's milk against aluminum chloride induced oxidative stress $^{[46]}$. Also Knoss ${ }^{[46]}$ have reported that camel's milk is very rich in trace elements such as Magnesium $(\mathrm{Mg})$ and zinc $(\mathrm{Zn}) . \mathrm{Mg}$ was found to protect cells form the toxic effect of heavy metals such as aluminum and cadmium. It was reported that there is an increase production of reactive oxygen species in patients with magnesium deficiency ${ }^{[75]}$. Also, $\mathrm{Mg}$ play a major role in the absorption and metabolism of Vitamin
$\mathrm{C}$ and $\mathrm{E}^{[76]}$. Thus helping our bodies in cell protection against free radicals.

Also, it has been reported that Vitamin E enhances the levels of reduced glutathione ${ }^{[76]}$. Recent study showed that magnesium is essential for synthesis of glutathione $^{[77]}$ and this may gives an idea about increased glutathione levels and in rats treated with camels milk.

$\mathrm{Zn}$ is an essential element required for many enzymes in our biological system. Zinc is very important in DNA replication, protein synthesis and cell division $^{[77]}$. Recent studies showed a relationship between antioxidant enzymes and zinc levels ${ }^{[78-81]}$, One study has shown that $\mathrm{Zn}$ deficiency in the diet paves the way for cell damage in the rat testis ${ }^{[82]}$. It has been reported that zinc deficiency resulted in increased lipid peroxidation in various rats tissues ${ }^{[81-84]}$.

Finally, we made a similar study to investigate the role of camel's milk in preventing the oxidative stress produced by oral administration of cadmium chloride and we found similar finding to our current study ${ }^{[85]}$.

\section{CONCLUSION}

Our results showed that oral administration of aluminum chloride into rats caused a marked alternation in hematological parameters such as decreased total erythrocytes count, decrease hemoglobin and hematocrite values and decreased serum iron levels. Also aluminum chloride led to increase lipid peroxidation and oxidative stress in the rats. Whereas the oral administration of Camel's milk prior the administration of aluminum chloride protect ed the erythrocytes from aluminum chloride induced oxidative damage and lipid peroxidation and maintained the mentioned hematological parameters within their normal levels.

\section{ACKNOWLEDGMENT}

The researcher thanks Mr. Mahmoud Alkhateeb from the department of physiology at medical college of King Khalid university for his contribution to the current work by helping in experimental designing and performing the biochemical measurements.

\section{REFERENCES}

1. Schetinger, M.R.C., V.M. Morsch and D. Bohrer, 2002. Aluminum: Interaction with nucleotides and nucleotidases and analytical aspects of $1 \mathrm{st}$ determination. Struct. Bond., 104: 99-138. http://direct.bl.uk/bld/PlaceOrder.do?UIN=121331 410\&ETOC $=$ RN\&from $=$ searchengine 
2. Domingo, J.L., M. Gméz, M.T. Llobet and J. Corbella, 1991. Influence of some dietary constituents on aluminum absorption and retention in rats. Kidney Int., 39:

598-601. http://www.ncbi.nlm.nih.gov/pubmed/2051716

3. El-Demerdash, F.M., 2004. Antioxidant effect of vitamin $\mathrm{E}$ and selenium on lipid peroxidation, enzyme activities and biochemical parameters in rats exposed to aluminum. J. Trace Elem. Med. Biol., 18: 113-121. http://www.ncbi.nlm.nih.gov/pubmed/15487771

4. Abbasali, K.M., T. Zhila and N. Farshad, 2005. Developmental toxicity of aluminum from high doses of $\mathrm{AlCl} 3$ in mice. J. Applied Res., 5: 575-579. http://www.jarcet.com/articles/Vol5Iss4/02Karimp our.pdf.

5. Cannata, J., J. Briggs, R. Junor and S. Fell, 1983. Aluminum hydroxide intake real risk of aluminum toxicity. Brit. Med. J., 286: 1937-1938. http://www.pubmedcentral.nih.gov/articlerender.fc gi? artid=1548249

6. Kaehny, W., A. Hegg and A. Alfrey, 1997. Gastrointestinal absorption of aluminum from aluminum containing antacids. New Engl. J. Med., 296: 1389-1390.

http://www.ncbi.nlm.nih.gov/pubmed/859546

7. Lione, A., 1985. Aluminum toxicity and the aluminum containing medication. J. Pharmacol. Therapy, 29: 255-285.

http://cat.inist.fr/?aModele $=$ afficheN\&cpsidt $=7862878$

8. Ochmanski, W. and W. Barabasz, 2000. Aluminum-occurrence and toxicity fororganisms. Przegl. Lek., 57: 665-668. http://www.ncbi.nlm.nih.gov/pubmed/11293216

9. Alfrey, A.C., G.R. LeGendre and W.D. Kaehny, 1976. The dialysis encephalopathy syndrome. Possible aluminum intoxication. N. Engl. J. Med., 294: 184-188.

http://www.ncbi.nlm.nih.gov/pubmed/1244532

10. Ward, M.K., T.G. Feest, H.A. Ellis, I.S. Parkinson and D.N. Kerr, 1978. Osteomalacic dialysis osteodystrophy: Evidence for a water-borne aetiological agent, probably aluminum. Lancet, 22: 841-845.

http://www.ncbi.nlm.nih.gov/pubmed/76795

11. Gupta, V.B., G. Anitha, M.L. Hegda, L. Zecca and R.M. Garruto et al., 2005. Aluminum in Alzheimer's disease: are we still at a crossroad? Cell. Mol. Life Sci., 62: 143-158. http://www.ncbi.nlm.nih.gov/pubmed/15666086
12. Campbell, A., 2002. The potential role of aluminum in Alzheimer's disease. Nephrol. Dial. Transplant., 17:

17-20. http://www.ncbi.nlm.nih.gov/pubmed/11904353

13. Short, A.I.K., R.J. Winney and J.S. Robson, 1980. Reversible microcytic hypochromic anaemia in dialysis patients due to aluminum intoxication. Proc. Eur. Dial. Transplant. Assoc., 17: 226-233. http://www.ncbi.nlm.nih.gov/pubmed/7243773

14. Caramelo, C.A., J.B. Cannata and M.R. Rodeles, 1995. Mechanism of aluminum-induced microcytosis: Lessons from accidental aluminum intoxication. Kidney Int., 47: 164. http://cat.inist.fr/?aModele $=$ afficheN\&cpsidt $=3451$ 611

15. Mahieu, S., M. Contini, M. Gonzalez, N. Millen and M.M Elias, 2000. Aluminum toxicity. Hematological effects. Toxicol.Lett., 111: 235-242. http://cat.inist.fr/?aModele=afficheN\&cpsidt $=1253882$

16. Zaman, K., W. Zaman and H. Siddique, 1993. Hematological and enzymatic results of aluminum intoxication in rats. Compar. Biochem. Physiol., 105: 73-76.

http://www.ncbi.nlm.nih.gov/pubmed/8101793

17. Wills, M.R. and J. Savory, 1983. Aluminum poisoning. Dialysis encephalopathy, osteomalacia and anemia. Lancet, 2: 29-34. http://www.ncbi.nlm.nih.gov/pubmed/6134894

18. Chmielnicka, J., M. Nasiadek, E. Lewandowska- Żyndul and R. Pińkowski, 1996. Effect of aluminum on hematopoiesis after intraperitoneal exposure in rats. Ecotoxic. Environ. Saf., 33: 201-206. http://www.ncbi.nlm.nih.gov/pubmed/8727512

19. Chmielnicka, J., M. Nasiadek and E. Lewandowska-Żyndul, 1993 Changes on activity of some enzymes in heme biosynthesis after intraperitoneal application of aluminum (in Polish). Acta Pol. Toxicol., 82: 212.

20. Touam, M., F. Martinez, B. Lacour, R. Bourdon, J. Zingraff, S. Giulio and T. Drueke, 1983. Aluminum-induced, reversible microcytic anemia in chronic renal failure: Clinical experimental studies. Clin. Nephrol., 19: 295-299. http://www.biomedexperts.com/Abstract.bme/6872 366/Aluminuminduced_reversible_microcytic_anemia_in_chronic _renal_failure_clinical_and_experimental_studies

21. Kaiser, L. and K.A. Schwartz, 1985. Aluminuminduced anemia. Am. J. Kidney Dis., 5: 348-352. http://www.ncbi.nlm.nih.gov/pubmed/3904427 
22. El-Demerdash, F.M., M.I. Yousef; F.S. Kedwany and H.H. Baghdadi, 2004. Role of $\alpha$-tocopherol and $\beta$-carotene in ameliorating the fenvalerateinduced changes in oxidative stress, hematobiochemical parameters and semen quality of male rats. J. Environ. Sci. Health Bull., 39: 443-459. http://cat.inist.fr/?aModele $=$ afficheN\&cpsidt $=1576$ 0824

23. Mansour, S., S. Alan and B.R. Norman, 2006. Aluminum-induced injury to kidney proximal effects on markers of oxidative damage. J. Trace Elem. Med. Biol., 19: 267-273. http://www.ncbi.nlm.nih.gov/pubmed/16443175

24. Moumen, R., N. Ait-Oukhatar, F. Bureau, C. Fleury, D. Bougle and P. Arhan, 2001. Aluminum increases xanthine oxidase activity and disturbs antioxidant status in the rat. J. Trace Elem. Med. Biol., 15: 89-93.

http://www.ncbi.nlm.nih.gov/pubmed/11787993

25. Anane, R. and E.E. Creppy, 2001. Lipid peroxidation as a pathway to aluminum cytotoxicity in human skin fibroblast cultures: Prevention by superoxide dismutase plus catalase and vitamins E and C. Hum. Exp. Toxicol., 20: 477-481. http://www.ncbi.nlm.nih.gov/pubmed/11776410

26. Fraga, C.G., P.I. Oteiza, M.S. Golub, M.E. Gershwin and C.L. Keen, 1990. Effects of aluminum on brain peroxidation. Toxicol. Lett., 51: 213-219. http://www.ncbi.nlm.nih.gov/pubmed/2330606

27. Chugh, S.N., A. Mittal, S. Seth and K. Chrugh, 1995. Lipid peroxidation in acute aluminum phosphide poisoning. J. Assoc. Physicians India, 38: 302-316.

http://www.ncbi.nlm.nih.gov/pubmed/8713267

28. Chugh, S.N., V. Arora, A. Sharma and K. Chrugh, 1996. Free radical scavengers and lipid peroxidation in acute aluminum phosphide poisoning. Indian J. Med. Res., 104: 190-193. http://www.ncbi.nlm.nih.gov/pubmed/8840658

29. Deloncle, R., F. Huguet, P. Babin, B. Fernandez, N. Quellard and O. Guillard, 1999. Chronic administration of aluminum L-glutamate in young mature rats: Effects on iron levels and lipid peroxidation in selected brain areas. Toxicol. Lett., 104: 65-73.

http://www.ncbi.nlm.nih.gov/pubmed/10048751

30. Yoshino, M., M. Ito, M. Haneda, R. Tsubouchi and K. Murakami, 1999. Prooxidant action of aluminum on-stimulation of iron-mediated lipid peroxidation by aluminum. Biometals, 12: 237-240. http://www.ncbi.nlm.nih.gov/pubmed/10581687
31. Vittori, D., A. Nesse, G. Pe'rez and G. Garbossa, 1999. Morphologic and functional alterations of erythroid cells induced by long-term ingestion of aluminum. J. Inorg. Biochem., 76: 113-120. http://www.ncbi.nlm.nih.gov/pubmed/10612063

32. Zatta, P., P. Zambenedetti, A. Toffoletti, C. Corvaja and B. Corain, 1997. Aluminum (III) induces alterations on the physical state of the erythrocytic membrane: An ESR evaluation. J. Inorg. Biochem., 65: 109-114. http://direct.bl.uk/bld/PlaceOrder.do?UIN=020121 $889 \&$ ETOC $=$ RN\& from $=$ searchengine

33. Mostaghie, A.A., 1988. Interrelationship between aluminum and iron metabolism in man $\mathrm{PhD}$ thesis). The University of Newcastle Upon Tyne, UK.

34. Mostaghie, A.A. and A.W. Skillen, 1986. Binding of aluminum to transferring and lactoferrin. Biochem. Soc. Trans., 14: 916-917.

35. Rahman, H., A.W. Skillen, S.M. Channon, M.K. Ward and D.N.S. Kerr, 1985. Methods for studying the binding of aluminum to serum proteins. Clin. Chim., 31: 1969-1973.

36. Trapp, G.A., 1983. Plasma aluminum is bound to transferrin. Life Sci., 33: 311-316. http://www.ncbi.nlm.nih.gov/pubmed/6410138

37. Golub, M.S., B. Han and C.L. Keen, 1999. Aluminum uptake and effects on transferrin mediated iron uptake in primary cultures of rat neurons, astrocytes and oligodendrocytes. Neurotoxicology, $\quad 20$ : 961-970. http://www.ncbi.nlm.nih.gov/pubmed/10693977

38. Skilen, A.W. and A.A. Mostaghie, 1986. The Effect of Aluminum on the Interaction Between Transferrin and Its Receptors on Human Placental Receptors. In: Aluminum and Other Trace Elements in Renal Disease, Taylor, A.W. (Ed.). Bailliere Tindal, London, ISBN: 0702011681, pp: 360.

39. Harris, W.R., 1996. Binding and transport of aluminum by serum proteins. Coord. Chem. Rev., 149: 347-365.

http://cat.inist.fr/?aModele $=$ afficheN\&cpsidt $=1095$ 3452

40. Nasiadek, M. and J. Chmielnicka, 2000. Interaction of aluminum with exogenous and endogenous iron in the organism of rats. Ecotoxicol. Environ. Safe., 45: 284-290.

http://cat.inist.fr/?aModele=afficheN\&cpsidt=1347292

41. Nasiadek, M., J. Chmielnicka and J. Subdys, 2001. Analysis of urinary phorphyrins in rats exposed to aluminum and iron. Ecotoxicol. Environ. Safe., 48: 11-17. DOI: 10.1006/eesa.2000.1999 
42. Morgan, E.H. and T.G. Redgrave, 1998. Effects of dietary supplementation with aluminum and citrate on iron metabolism in the rat. Biol. Trace Elem. Res., 65: 117-131. DOI: 10.1007/BF02784264

43. Alfrey, C., 1984. Aluminum intoxication. New Engl. J. Med., 310: 1113-1114.

44. Ebina, Y., S. Okada, S. Hamazaki and O. Midorikawa, 1984. Liver, kidney and central nervous system toxicity of aluminum given intraperitoneally to rats a multiple-dose subchronic study using aluminum nitro triacetate. J. Toxicol. Appl. Pharmacol., 75: 211-218.

http://www.ncbi.nlm.nih.gov/pubmed/6433509

45. Testolin, G., D. Erba, D. Ciappellano and G. Bermano, 1996. Influence of organic acids on aluminum absorption and storage in rat tissues. Food Addit. Contam., $\quad$ 13: 21-27. http://www.ncbi.nlm.nih.gov/pubmed/8647304

46. Knoess, K.H., 1979. Milk production of the dromedary. Proceeding of the IFS Symposium Camels. Sudan, pp: 201-214.

47. Rao, M.B., R.C. Gupta and N.N. Dastur, 1970. Camels' milk and milk products. Ind. J. Dairy Sci., 23: 71-78.

48. Biuletyn Informacyjny Instytutu Lekw. Numer Specjalny 3, 1988.

49. Gramiccioni, L., G. Ingrao, M.R. Milana, P. Santaroni and G. Tomassi, 1996. Aluminum levels in Italian diets and in selected foods from aluminum utensils. Food. Addit. Contam., 13: 767. http://www.ncbi.nlm.nih.gov/pubmed/8885317

50. Starska, K., 1993. Aluminum in food. Rocz. Państw. Zakł. Hig., 44: 55.

51 Sepe, A., S. Costantini, L. Ciaralli, M. Ciprotti and R. Giordano, 2001. Evaluation of aluminum concentrations in samples of chocolate and beverages by electrothermal atomic absorption spectrometry. Food. Addit. Contam., 18: 788-196. http://www.ncbi.nlm.nih.gov/pubmed/11552746

52. Strumia, M.M., A.B. Sample and E.D. Hart, 1954. An improved micro hematocrite method. Am. J. Clin. $\quad$ Pathol., 24: 1016-1026. http://www.ncbi.nlm.nih.gov/pubmed/13197333

53. Drabkin, D.L. and J.H. Austin, 1993. Spectrophotometer studies for common hemoglobin derivatives in human; Dog and rabbit. J. Biol. Chem., 98: 719-725.

54. Wintrobe, M.M., 1956. Clinical Haematology. 3rd Edn., Philadelphia, pp: 96-99.
55. Okhawa, H., N. Ohigni and K. Yagi, 1979. Assay of lipid peroxides in animal tissues by thiobarbituric acid reaction. Anal. Biochem., 95: 351-358.

http://www.ncbi.nlm.nih.gov/pubmed/36810

56. Zaman, K. and A.J. Zaman, 1993. Batcabe Hematological effects of aluminum on living organisms. Comp. Biochem. Physiol., 106: 285-293. http://cat.inist.fr/?aModele=afficheN\&cpsidt $=3902675$

57. Corain, B., 1992. The solution state of aluminum (III) as relevant to experimental toxicology: Recent data and new perspectives. Coord. Chem. Rev., 112: 19-32.

http://cat.inist.fr/?aModele $=$ afficheN\&cpsidt $=5134584$

58. Fulton, B. and E.H. Jeffery, 1994. Heme oxygenase induction: a possible factor in aluminum-associated anemia. Biol. Trace Element Res., 40: 9-19. http://www.ncbi.nlm.nih.gov/pubmed/7511925

59. Gutteridge, J.M.C., G.J. Quinlan, I. Clark and B. Halliwell, 1985. Aluminum salts accelerate peroxidation of membrane lipids stimulated by iron salts. Biochim. Biophys. Acta, 835, 441-447. http://www.ncbi.nlm.nih.gov/pubmed/2861853

60. Zaman, K., H. Miszta and Z. Dąbrowski, 1990. The effect of aluminum upon the activity of selected bone marrow enzymes in rats. Folia Haematol., 3: 447-451. http://www.ncbi.nlm.nih.gov/pubmed/1703115

61. Ganchev, T., E. Dyankov, R. Zacharieva, I. Pachalieva, M. Velikova and B. Kavaldjieva, 1998. Influence of aluminum on erythropoiesis, iron metabolism and some functional characteristics of erythrocytes in rats. Acta Physiol. Pharmacol. Bulg., 23: 27-31. http://www.ncbi.nlm.nih.gov/pubmed/10347617

62. De Maeyer, E. and M.Adiels- Tegman, 1985. The prevalence of anemia in the world. World Health Stat., 38: 302-316. http://db.jhuccp.org/icswpd/exec/icswppro.dll?BU=http://db.jhuccp.org/icswpd/exec/icswppro.dll\&QF0=DocNo\&QI0=03326 2\&TN=Popline \&AC $=$ QBE_QUERY \&MR=30\%25 $\mathrm{DL}=1 \& \& \mathrm{RL}=1 \& \& \mathrm{RF}=$ LongRecordDisplay $\& \mathrm{DF}=$ LongRecordDisplay

63. Skikne, B.S., C.H. Flowers and J.D. Cook, 1990. Serum transferrin receptor: A quantitative measure of tissue iron deficiency. Blood, 75: 1870-1876. http://www.ncbi.nlm.nih.gov/pubmed/2331526

64. Rees, D.C., B.M. Singh, L.Y. Lou, S. Wickramasinghe and S.L. Thein, 1997. Nontransfusional iron overload in thalassemia. Association with hereditary hemochromatosis. Ann. N.Y. Acad. Sci., 850: 490-494.

http://bloodjournal.hematologylibrary.org/cgi/conte nt/full/90/8/3234 
65. VanLandeghem, G.F., P.C. Dhaese, L.V. Lamberts and M. DeBroe, 1997. Competition of iron and aluminum for transferrin: The molecular basis for aluminum deposition in iron-overloaded dialysis patients. Exp. Nephrol., 5: 239-245. http://direct.bl.uk/bld/PlaceOrder.do?UIN=026787 $725 \&$ ETOC $=\mathrm{RN} \&$ from $=$ searchengine

66. Joshi, J.G., 1990. Aluminum, a neurotoxin which affects diverse metabolic reactions. Biofactors, 2: 163-169. http://www.ncbi.nlm.nih.gov/pubmed/2198876

67. Kong S, S. Liochev and I. Fridovich, 1992. Aluminum (III) facilitates the oxidation of NADH by the superoxide anion. Free Radic. Biol. Med., 13:79-81.

http://cat.inist.fr/?aModele $=$ afficheN\&cpsidt $=4550$ 801

68. Sibmooh, N., B. Pipitaporn, P. Wilairatana, J. Dangdoungjai, R. Udomsangpetch, S. Looareesuwan and U. Chantharaksri, 2000. Effect of artemisinin on lipid peroxidation and fluidity of the erythrocyte membrane in malaria. Biol. Pharmacol. Bull., 23: 1275-1280.

http://cat.inist.fr/?aModele $=$ afficheN\&cpsidt $=8242$ 82

69. Mena, P., M. Maynar, J.M. Gutierrez, J. Maynar, J. Timon and J.E. Campillo, 1991. Erythrocyte free radical scavenger enzymes in bicycle professional racers. Adaptation to training. Int. J. Sports Med., 12: 563-566.

http://cat.inist.fr/?aModele $=$ afficheN\&cpsidt $=5595$ 329

70. Valentini, J., G.C. Schmitt, D. Grotto, L.D. Santa Maria and S.P. Boeira et al., 2007. Human erythrocyte delta-aminolevulinate dehydratase activity and oxidative stress in hemodialysis patients. Clin. Biochem., 40: 591-594.

http://www.ncbi.nlm.nih.gov/pubmed/17462617

71. Shainkin Kestenbaum, R., C. Caruso and G.M. Berlyne, 1990. Reduced superoxide dismutase activity in erythrocytes of dialysis patients: a possible factor in the etiology of uremic anemia. Nephron., 55: 251-253. http://content.karger.com/ProdukteDB/produkte.as $\mathrm{p}$ ?Doi $=185970$

72. Hasanoglu, E., N. Altan, S. Sindel, C.O. Ongun, M. Bali and E. Altintazs, 1994. The relationship between erythrocyte superoxide dismutase activity and plasma levels of some trace elements ( $\mathrm{Al}, \mathrm{Cu}, \mathrm{Zn}$ ) of dialysis patients. Gen. Pharmacol., 25: 107-110. http://www.ncbi.nlm.nih.gov/pubmed/8026695
73. Abd-Elghaffar, S.K.H, G.H. El-Sokkary and A.A. Sharkawy, 2005. Aluminum-induced neurotoxicity and oxidative damage in rabbits: Protective effect of melatonin. Neuro. Endocrinol. Lett., 26: 609-616. http://www.ncbi.nlm.nih.gov/pubmed/16264393

74. Serra, M.A., V. Barassi, C. Canavese and E. Sabbioni, 1991. Aluminum effect on the activity of superoxide dismutase and of other antioxygenic enzymes in vitro. Biol. Trace Elem. Res., 31: 79-96. http://www.ncbi.nlm.nih.gov/pubmed/1724179

75. Martin, H., L. Richert and A. Berthelot, 2003. Magnesium deficiency induces apoptosis in primary cultures of rat hepatocytes. Am. Soc. Nutr. Sci. J. Nutr., 133: 2505-2511. http://jn.nutrition.org/cgi/content/full/133/8/2505

76. Barbagallo, M., 1999. Effects of vitamin $\mathrm{E}$ and glutathione on glucose metabolism: Role of magnesium. Hypertension, 34: 1002-1006. http://cat.inist.fr/?aModele $=$ afficheN\&cpsidt $=1187$ 447

77. Virginia, M., M.B. Smith, M.J. Brauner and W. PhiliMajerus, 1971. Glutathione biosynthesis in human erythrocytes. J. Clin. Invest., 50: 507-513. http://www.pubmedcentral.nih.gov/articlerender.fc gi?artid $=442063$

78. Powell, S.R., 2000. Antioxidant properties of zinc. J. Nutr., 130: 1447-1454. http://cat.inist.fr/?aModele $=$ afficheN $\&$ cpsidt $=1434$ 481

79. Ozturk, A., A.K Baltaci, R. Mogulkoc, E. Oztekin, A. Sivrikaya, E. Kurtogh and A. Kul, 2003. Effects of zinc deficiency and supplementation on malondialdehyde and glutathione levels in blood and tissue of rats performing swimming exercice. Biol. Trace Elem. Res., 94: 157-166. http://www.ncbi.nlm.nih.gov/pubmed/14716102

80. Ozdemir, G. and F. Inanc, 2005. Zinc may protect remote ocular injury caused by intestinal ischemia reperfusion in rats. Tohoku J. Exp. Med., 206: 247-251. http://www.ncbi.nlm.nih.gov/pubmed/15942153

81. Sato, M. and I. Bremner. 1993. Oxygen free radicals and metalothionein. Free Radic. Biol Med., 14: 325-327. http://www.ncbi.nlm.nih.gov/pubmed/8458590

82. Shaheen, A.A. and A.A. El-Fattah, 1995. Effect of dietary zinc on lipid peroxidation, glutathione, protein levels and superoxide dismutase activity in rat tissues. Int. J. Biochem. Cell. Biol., 27: 89-95. http://www.ncbi.nlm.nih.gov/pubmed/7757885 
83. Bray, T.M. and W.J. Bettger, 1990. The physiological role of zinc as an antioxidant. Free Radic. Biol. Med., 8: 281-91. http://grande.nal.usda.gov/ibids/index.php?mode2= detail\&origin=ibids_references\&therow $=271915$

84. Goering, P.L. and C.D. Klaassen, 1984. Zincinduced tolerance to cadmium hepatotoxicity Toxicol. Applied Pharmacol., 74: 299-307. http://www.ncbi.nlm.nih.gov/pubmed/6740679
85. AL-Hashed, F., M. Dallak, N. Bashir, M. Abbas, R. Elessa, M. Khalil and M. Alkhateeb, 2009. Camel's Milk protects against cadmium chloride induced toxicity in white albino rats. Am. J. Pharm. Toxicol., 4: 107-111. http://www.scipub.org/fulltext/AJPT/AJPT43107117.pdf 